Impelementasi Pendidikan Karakter....(Arzet Mamelio, Muhamad Idris, Adrianus Dedy)

\title{
IMPLEMENTASI PENDIDIKAN KARAKTER DALAM PEMBELAJARAN PENDIDIKAN KEWARGANEGARAAN PADA PESERTA DIDIK SDN 1 UJUNG TANJUNG
}

\author{
Oleh: Arzet Mamelio, Muhamad Idris, Adrianus Dedy \\ Email: arzetmamelio28@gmail.com \\ (Universitas PGRI Palembang)
}

\begin{abstract}
Abstrak
Penelitian ini memiliki tujuan yakni untuk mendeskripsikan Implementasi Pendidikan Karakter dalam Pembelajaran Pendidikan Kewarganegaraan pada Peserta Didik SDN 1 Ujung Tanjung. Penelitian ini menggunakan rancangan penelitian kualitatif deskriptif. Teknik pengumpulan data yang digunakan dalam penelitian ini meliputi observasi, wawancara, dan dokumentasi sedangkan Teknik analisis data meliputi reduksi data, penyajian data, dan kesimpulan. Hasil penelitian menunjukkan bahwa implementasi pendidikan karakter disiplin dalam mata pelajaran pendidikan kewarganegaraan di SDN 1 Ujung Tanjung sudah baik, hal ini terbukti dari peraturan yang ada di sekolah bahwa tidak bleh datang terlambat, berpakaian harus rapi sesuai dengan peraturan sekolah, berdoa sebelum belajar walaupun guru kelas belum ada di kelas, selalu mematuhi peraturan guru, serta peserta didik mematuhi peraturan dan tata tertib di sekolah dan juga terbukti dari nilai raport yang di dapat peserta didik yaitu di atas nilai rata-rata KKM mata pelajaran Pendidikan Kewarganegaraan.
\end{abstract}

Kata Kunci: Pendidikan Karakter, Disiplin, Pembelajaran PKn

\section{IMPLEMENTATION OF CHARACTER EDUCATION IN THE LEARNING OF CITIZENSION EDUCATION IN STUDENTS OF SDN 1 UJUNG TANJUNG}

\begin{abstract}
This study has the objective of describing the implementation of character education in learning citizenship education for students at SDN 1 Ujung Tanjung. This study used a descriptive qualitative research design. Data collection techniques used in this study include observation, interviews, and documentation, while data analysis techniques include data reduction, data presentation, and conclusions. The results showed that the implementation of disciplinary character education in civic education subjects at SDN 1 Ujung Tanjung was already good, this is evident from the existing regulations in schools that do not come late, dress must be neat in accordance with school regulations, pray before studying even though the class teacher not yet in class, always obey the teacher's rules, and students comply with the rules and regulations at school and it is also evident from the report card value that students get, which is above the KKM average value in the Citizenship Education subject.
\end{abstract}

Keywords: Character Education, Discipline, Civics Learning 


\section{A. PENDAHULUAN}

Pendidikan merupakan hal yang sangat penting bagi kehidupan bangsa dan negara, karena dari pendidikan inilah kita dapat membangun karakter, kecerdasan dan kepribadian peserta didik menjadi lebih baik dengan adanya pendidikan tersebut. Oleh sebab itu, pendidikan di Indonesia terus menerus dibangun dan dikembangkan agar proses pelaksanaannya menghasilkan generasi yang diharapkan mampu membuat bangsa Indonesia menjadi lebih baik dari sebelumnya. Jenjang Pendidikan di Indonesia dimulai dari Taman Kanak-kanak (TK) atau Pendidikan Anak Usia Dini (PAUD), Sekolah Dasar (SD), Sekolah Menegah Pertama (SMP), dan Sekolah Menengah Atas (SMA) (Sutiyono, 2014).

Pendidikan Sekolah Dasar merupakan lembaga yang dikelola dan diatur oleh pemerintah yang bergerak di bidang pendidikan dasar, diselenggarakan secara formal selama 6 (enam) tahun dari kelas I sampai kelas VI untuk peserta didik di seluruh Indonesia. Dalam pelaksanaannya, kurikulum pendidikan di Sekolah Dasar yang diajarkan kepada peserta didik meliputi sejumlah mata pelajaran wajib yang harus dikuasainya. Mata pelajaran tersebut antara lain: Bahasa Indonesia, Ilmu Pengetahuan Alam, Pendidikan Kewarganegaraan, Ilmu Pengetahuan Sosial, Pendidikan Jasmani dan Olahraga, Seni Budaya dan Kerajinan, serta Matematika.

Pendidikan karakter merupakan salah satu komponen penting dalam Pendidikan Kewarganegaraan SD. Karakter merupakan hal sangat esensial dalam berbangsa dan bernegara, hilangnya karakter akan menyebabkan hilangnya generasi penerus bangsa. Karakter berperan sebagai "kemudi" dan kekuatan sehingga bangsa ini tidak terombang-ambing. Karakter tidak datang dengan sendirinya, tetapi harus dibangun dan dibentuk untuk menjadi bangsa yang bermartabat. Dalam konteks kebangsaan, pembangunan karakter diorientasikan pada 3 (tiga) tataran besar, yaitu: 1) untuk menumbuhkan dan memperkuat jati diri bangsa; 2) untuk menjaga keutuhan Negara Kesatuan Republik Indonesia (NKRI); dan 3) untuk membentuk manusia dan masyarakat Indonesia yang berakhlak mulia dan bangsa yang bermartabat”. 
Impelementasi Pendidikan Karakter....(Arzet Mamelio, Muhamad Idris, Adrianus Dedy)

Pendidikan karakter merupakan bentuk kegiatan manusia yang di dalamnya terdapat suatu tindakan yang mendidik diperuntukkan bagi generasi selanjutnya. Tujuan pendidikan karakter adalah untuk membentuk penyempurnaan diri individu secara terus-menerus dan melatih kemampuan diri demi menuju ke arah hidup yang lebih baik (Kusuma dalam Juliardi, 2015).

Berdasarkan hasil wawancara peneliti di SDN 1 Ujung Tanjung dengan ibu Sumarni, S.Pd.SD selaku guru kelas IV yang mengajar di SDN 1 Ujung Tanjung, hasil wawancara tersebut peneliti Simpulkan bahwa masalah karakter yang ada di kelas IV SDN 1 Ujung Tanjung yaitu kurangnya disiplin siswa yang terlihat dalam indikasi sebagai berikut: datang terlambat, bullying, sering ribut di kelas, kurang paham dalam pembelajaran, tidak bertanggung jawab dalam melaksanakan piket kelas dan masih ada lagi permasalahan karakter lainnya.

Disiplin merujuk pada instruksi sistematis yang diberikan kepada peserta didik (disciple). Disiplin berarti kontrol penguasaan diri terhadap impuls yang tidak inginkan atau proses mengarahkan impuls pada suatu cita-cita atau tujuan tertentu untuk mencapai dampak yang lebih besar (Husdarta dalam Lestariningsih, 2017). Berdasarkan latar belakang yang telah diuraikan, maka peneliti tertarik untuk melakukan penelitian dengan judul "Implementasi Pendidikan Karakter dalam Pembelajaran Pendidikan Kewarganegaraan (PKn) pada siswa SDN 1 Ujung Tanjung Tahun 2020”.

\section{B. METODOLOGI PENELITIAN}

Penelitian ini menurut klasifikasi bidangnya termasuk dalam bidang penelitian pendidikan atau akademis. Penelitian ini dilaksanakan menggunakan pendekatan kualitatif, dan jenis penelitian ini adalah penelitian deskriptif. Peneliti menggunakan pendekatan dan jenis penelitian ini, karena peneliti ingin mendeskripsikan suatu fenomena yang sesuai dengan keadaan sebenarnya yang dialami subjek penelitian dan menyajikan data tersebut dalam bentuk kata-kata.

Menurut Sugiono (2016, p.9) "metode penelitian kualitatif adalah metode penelitian yang berlandaskan pada filsafat postpositivisme". Digunakan untuk meneliti pada kondisi obyek yang alamiah, (sebagai lawannya adalah eksperimen) 
dimana peneliti adalah sebagai instrumen kunci, teknik pengumpulan data dilakukan secara triangulasi (gabungan), analisis data bersifat induktif atau kualitatif, dan hasil penelitian kualitatif lebih menekankan makna dari pada generalisasi

Dalam penelitian ini, peneliti akan melakukan penelitian di SDN 1 Ujung Tanjung tahun 2020. Pada saat akan mengadakan penelitian, peneliti mengumpulkan data dengan teknik, yaitu: (a) observasi, (b) wawancara, (c) dokumentasi dan catatan lapangan. Dengan menggunakan teknik tersebut, peneliti menggunakan instrumen sebagai pedoman dalam mengambil data. Namun, dalam hal tersebut kemungkinan peneliti mengambil data di luar instrumen yang sudah direncanakan, jika terlihat banyak masalah yang mungkin saja berkembang setelah peneliti terun langsung ke lapangan.

\section{HASIL PENELITIAN DAN PEMBAHASAN}

Implementasi pendidikan karakter dalam pembelajaran Pendidikan Kewarganegaraan pada kelas IV SDN 1 Ujung Tanjung. Implementasi pendidikan karakter dalam pembelajaran Pendidikan Kewarganegaraan pada kelas IV SDN 1 Ujung Tanjung ini yang akan dibahas mengenai perencanaan dan pelaksanaan pendidikan karakter dalam pembelajaran Pendidikan Kewarganegaraan.

Sebelum melaksanakan pembelajaran, guru terlebih dahulu membuat perencanaan seperti silabus dan RPP. Kedua perencanaan ini merupakan hal yang harus ada dalam proses belajar mengajar. Berdasarkan hasil analisis peneliti silabus dan RPP yang digunakan oleh guru secara keseluruhan telah menunjukkan adanya pendidikan karakter dalam pembelajaran Pendidikan Kewarganegaraan. Hal tersebut dapat terlihat dari RPP dan pendekatan yang digunakan guru dalam kegiatan proses pembelajaran.

Hal ini berarti telah sesuai dengan pendapat Peterson dalam Wardani (2019) menjelaskan bahwa pendidikan karakter adalah suatu istilah yang luas, yang digunakan untuk menggambarkan kurikulum dan ciri-ciri organisasi yang mendorong pengembangan nilai-nilai fundamental peserta didik di sekolah. 
Impelementasi Pendidikan Karakter....(Arzet Mamelio, Muhamad Idris, Adrianus Dedy)

Berdasarkan hasil penelitian bahwa guru telah mengintegrasikan nilai karakter disiplin di dalam pembelajaran Pendidikan Kewarganegaraan. Guru telah menciptakan pembelajaran yang interaktif dan dialogis dengan menerapkan beberapa metode pembelajaran. Guru juga telah menciptakan suasana belajar yang membuat peserta didik berkompetensi secara sehat melalui berbagai penugasan dan metode pembelajaran bervariasi.

Implementasi pendidikan karakter dalam pembelajaran Pendidikan Kewarganegaraan terlihat dari mulai pembelajaran hingga kegiatan penutup. Hal ini berarti telah sesuai dengan pendapat Elkind \& Sweet dalam Mahmud (2014, p.23) menyatakan bahwa pendidikan karakter adalah upaya yang disengaja untuk membantu memahami manusia, peduli dan inti atas nilai-nilai etis/susila. Yang dimana kita berpikir tentang macam-macam karakter yang kita inginkan untuk anak kita, ini jelas bahwa kita ingin mereka mampu untuk menilai apa itu kebenaran, sangat peduli tentang apa itu kebenaran atau sebenarnya, bahkan dalam menghadapi tekanan maupun godaan.

Selanjutnya dalam pelaksanaan proses pembelajaran, guru melakukan kegiatan spontan kepada peserta didik yang berdoa dengan sikap yang kurang baik dan berpakaian tidak rapi, hal tersebut perlu guru lakukan karena kegiatan tersebut terkadang peserta didik tidak mengetahui bahwa apa yang dilakukannya tersebut salah, dengan kegiatan spontan yang dilakukan guru tersebut akan memberikan dampak kepada peserta didik itu sendiri sehingga tidak mengulanginya kembali.

Dalam hal kedisiplinan, guru melatih peserta didik untuk disiplin dalam berpakaian, disiplin dalam menghargai waktu serta membawa berbagai kelengkapan belajar dan penugasan. Jika ada peserta didik yang tidak disiplin maka guru akan mencatatnya kemudian peserta didik tersebut akan di nasehati.

Berdasarkan hasil penelitian yang relevan menurut Juliardi (2015) dia berpendapat bahwa Pendidikan Kewarganegaraan merupakan salah satu sarana yang tepat untuk mengimplementasikan nilai-nilai dalam pendidikan karakter kepada peserta didik, karena tujuan Pendidikan Kewarganegaraan pada dasarnya adalah untuk menciptakan peserta didik menjadi warga yang demokratis dan 
berkarakter sesuai dengan nilai-nilai Pancasila, serta peneliti membandingkan dengan hasil nilai raport yang diperoleh peserta didik dalam mata pelajaran Pendidikan Kewarganegaraan di SDN 1 Ujung Tanjung sudah baik, hal itu terbukti dari nilai yang di dapat peserta didik yaitu di atas nilai rata-rata KKM mata pelajaran Pendidikan Kewarganegaraan.

Maka berdasarkan pembahasan di atas peneliti menyimpulkan bahwa implementasi pendidikan karakter dalam pembelajaran Pendidikan Kewarganegaraan di SDN 1 Ujung Tanjung terutama karakter disiplin sudah baik diterapkan terbukti dari peraturan yang ada disekolah bahwa tidak boleh datang terlambat ke sekolah, berpakaian harus rapi, selalu berdoa sebelum belajar walaupun guru belum ada dikelas, selalu mematuhi perintah guru, serta peserta didik mematuhi peraturan dan tata tertib yang ada di sekolah.

\section{SIMPULAN}

Berdasarkan hasil dari penelitian tentang Implementasi pendidikan karakter dalam pembelajaran Pendidikan Kewarganegaraan kelas IV di SDN 1 Ujung Tanjung dapat ditarik kesimpulan sebagai berikut:

1. Perencanaan pendidikan karakter dalam pembelajaran pendidikan kewarganegaraan pada kelas IV di SDN 1 Ujung Tanjung baik. Hal ini terlihat dari hasil nilai raport peserta didik pada mata pelajaran Pendidikan Kewarganegaraan.

2. Pelaksanaan perencanaan pendidikan karakter dalam pembelajaran Pendidikan Kewarganegaraan pada kelas IV SDN 1 Ujung Tanjung baik. Hal itu terbukti dari nilai raport pada mata pelajaran Pendidikan Kewarganegaraan.

3. Evaluasi pendidikan karakter dalam pembelajaran Pendidikan Kewarganegaraan pada kelas IV SDN 1 Ujung Tanjung dengan melakukan penilaian authentic atau pengamatan pada lembar kerja peserta didik, pengetahuan, keaktifan dan kerja sama peserta didik. Implementasi pendidikan karakter dalam pembelajaran Pendidikan Kewarganegaraan kelas IV di SDN 1 Ujung Tanjung secara garis besar sudah dilaksanakan 
Impelementasi Pendidikan Karakter....(Arzet Mamelio, Muhamad Idris, Adrianus Dedy)

secara baik. Hal ini terbukti dari nilai raport peserta didik pada mata pelajaran Pendidikan Kewarganegaraan.

\section{DAFTAR PUSTAKA}

Juliardi, B. (2015). Implementasi Pendidikan Karakter Melalui Pendidikan Karakter. Jurnal.

Lestariningsih, D. (2017). Implementasi Pendidikan Karakter Nilai Disiplin dan Tanggung Jawab dalam Mata Pelajaran Penjaskes pada Kelas IV. Jurnal.

Mahmud. (2014). Pendidikan Karakter. Bandung: Alfabeta.

Sugiyono. (2016). Metode Penelitian Kualitatif Kuantitatif dan $R \& D$. Bandung: Alfabeta.

Sutiyono, S. (2014). Impelemntasi Pendidikan Karakter pada Mata Pelajaran Pendidikan Kewarganegaraan Kelas IV di MI Darul Ulum Watesngalian Semarang. Skripsi.

Wardani, W. (2019). Implementasi Pendidikan Karakter Melalui Pembelajaran Tematik pada Peserta Didik di Sekolah Dasar. Skripsi. 